eth, roedd ei ymroddiad i'w deulu yn ddi-ball. Cyfarfu ei wraig, Eirian, pan oeddynt yn fyfyrwyr yn gweithio ar y fferi rhwng Caergybi a Dun Laoghire yn ystod eu gwyliau haf, a gofyn iddi ei briodi ar ôl dim ond naw diwrnod. Cawsant eu bendithio â dwy ferch, Alison a Jennifer, a phedwar o wyrion yr oedd yn meddwl y byd ohonyn nhw.

David Meacher

\section{GARRY SIME}

\section{8-2016}

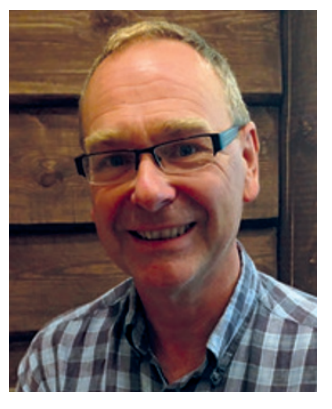

Our colleague and friend Garry

Sime died suddenly in the early hours of 13 February 2016. Garry was a highly respected and liked colleague who has left an indelible imprint on the lives of many young dentists who had the benefit of his teaching in hospital and community settings in Scotland and Wales.

Garry qualified from Glasgow as a dentist in 1982 having taken the slightly extended route via an intercalated BSc in Physiology. Working life began with house jobs which entitled him to sit FDS, again in Glasgow, after which he broadened his experience by working as an associate in general practice and as a community dental officer. The offer of a senior dental officer post saw Garry move to Clwyd where he and his young family settled in 1993. They really enjoyed their sojourn in Wales but the call of home was strong, and the opportunity to take up a senior post in Tayside brought Garry, Elizabeth and Euan to Perth. Here Garry continued his career development, becoming the Deputy Clinical Director for NHS Tayside and being included in the new specialist list for special care dentistry.
Garry was a superb clinician and provided all his patients with the best and most suitable treatment available. At heart he was a teacher and his final role within NHS Tayside was as the Outreach lead in Broxden Dental Centre in Perth. Aspiring dentists and therapist/ hygienists benefited from Garry's inexhaustible patience and encyclopaedic knowledge as well as his clinical skill. Garry's last professional act was to chair the SDCEP Anticoagulant Report Group.

This clinical skill and Garry's compassion benefitted people around the world as he undertook charitable work in Peru, Kenya and Albania. When not working at home or abroad, Garry enjoyed the great outdoors, initially as a walker and latterly as a runner. From being 'unable to run the distance between two lampposts', he ran 5k in his kilt, half marathons and, in 2014, the full Dundee marathon. The following year he climbed Kilimanjaro. A treasured photograph is of him at the summit, exhausted, exhilarated and clutching a mini Saltire with his name misspelt. He was also a competitive baker, albeit within the confines of the dental centre.

Garry, Elizabeth and Euan were active members of their church, Letham St Marks. Their shared profound faith made his passing bearable and Garry left this life without fear.

Morag Curnow 